\title{
KINERJA INSTRUKTUR PENDIDIKAN DAN PELATIHAN KETERAMPILAN PADA PANTI SOSIAL BINA REMAJA MAJAR TABELA KOTA PALANGKA RAYA
}

\author{
Performance Of Educational Instructors And Skills Training In The Youth Nursing \\ Community Of Majar Tabela City Palangka Raya
}

\section{Sonedi* \\ Lelisa Noviyanti}

Universitas Muhammadiyah Palangkaraya, Palangka Raya, Central Kalimantan, Indonesia

email: sonedi@umpalangkaraya.ac.id

\begin{abstract}
Abstrak
Penelitian ini bertujuan untuk mengetahui, mendeskripsikan dan menganalisis kinerja instruktur pendidikan dan pelatihan keterampilan pada Panti Sosial Bina Remaja Majar Tabela Kota Palangka Raya. Sedangkan metode penelitian yang digunakan adalah metode kualitatif. Peneliti ingin mendeskripsikan dan menganalisis kinerja instruktur pendidikan dan pelatihan keterampilan pada Panti Sosial Bina Remaja Majar Tabela dilihat dari 6 (enam) aspek yaitu quality, quantity, timeliness, cost effectiveness, need for supervision dan interpersonal impact. Sumber data terdiri dari sumber data primer yakni hasil wawancara dengan 4 (empat) orang instruktur, 2 (dua) orang siswa/klien, dan Kepala Sub Tata Usaha yang mewakili Kepala Panti Sosial Bina Remaja (PSBR) Majar Tabela, sedangkan sumber data skunder berupa dokumen resmi dari Panti Sosial Bina Remaja (PSBR) Majar Tabela.

Hasil penelitian menunjukkan bahwa kinerja instruktur masih kurang optimal. Hal ini bisa dilihat dari aspek quantity yaitu masih kurangnya jumlah instruktur yang ada minimal 6 (enam) sampai 8 (delapan) orang, sedangkan yang ada sekarang hanya 4 (empat) instruktur saja. Kemudian dari aspek need for supervision, masih ada instruktur yang kurang mandiri, khususnya berkaitan dengan pembuatan laporan dan evaluasi pembelajaran. Hal ini disebabkan instruktur tersebut merupakan instruktur yang baru direkrut sehingga masih kurang berpengalaman dalam membuat laporan dan evaluasi kegiatan. Sehingga menyebabkan aspek timeliness juga terdampak dengan keterlambatan dalam membuat laporan kegiatan. Untuk itu disarankan Kepala Panti Sosial Bina Remaja (PSBR) Majar Tabela Kota Palangka Raya yakni I) menambah jumlah instruktur yang sudah berpengalaman di bidangnya, baik di bidang otomotif maupun menjahit, 2) memberikan bimbingan teknis kepada instruktur baru sehingga bisa mandiri (need for supervision) dan tepat waktu (timeliness) dalam membuat laporan akhir maupun evaluasi kegiatan, dan 3) meninjau kembali besaran honor instruktur guna meningkatkan komitmen instruktur sehingga meningkatkan kinerja instruktur.
\end{abstract}

\begin{abstract}
This research aims to find out, describe and analyze the performance of educational instructors and skills training at the youth community Development of Majar Tabela City Palangka Raya. While the research method used is qualitative. Researchers want to describe and analyze the performance of educational instructors and skill training at the Majar Tabela Youth Development Community in the six (6) Aspects of quality, quantity, timeliness, cost-effectiveness, need for supervision and Interpersonal impact. Data sources consist of primary data sources, which are interviews with 4 (four) instructors, 2 (two) Students/clients, and the head of Sub administration representing the head of Youth Development (PSBR) Majar Tabela, while the secondary data source is Official document of the Youth Development Community (PSBR) Majar Tabela.
\end{abstract}

The results showed that the instructor's performance was still less than optimal. This can be seen from the quantity aspect is still a lack of instructors there are at least 6 (six) to 8 (eight) people, while the one is now only 4 (four) instructors. Then, from the need for supervision aspect, there are still less independent instructors, especially with regards to the creation of reports and learning evaluations. This is because the instructor is newly recruited so that it is still less experienced in making reports and evaluation activities. Thus causing the timeliness aspect is also impacted by delays in making activity reports. Therefore, the head of Youth Development Social Orphanage (PSBR) Majar Tabela City Palangka Raya is I) increasing the number of instructors who are experienced in their field, both in the field of automotive and sewing, 2) provide technical guidance to the new instructor So that it can be independent (need for supervision) and timeliness in making final reports as well as evaluation of activities, and 3) reviewing the honor of the instructor to improve the instructor's commitment to improve the performance of instructors. 


\section{PENDAHULUAN}

Penanganan masalah kesejahteraan sosial anak remaja terlantar merupakan kewajiban pemerintah, dalam hal ini ada pada suatu lembaga yang disebut dengan panti sosial atau panti rehabilitasi sosial. Salah satu tugas dari pada sebuah lembaga Panti Sosial adalah memberikan ilmu pengetahuan berupa pendidikan dan pelatihan keterampilan sebagai bekal kepada setiap anak asuh agar kelak dapat hidup mandiri di tengah masyarakat. Hal ini Mengingat Undang-Undang Nomor II Tahun 2009 tentang Kesejahteraan Sosial pasal I menyebutkan bahwa "kesejahteraan sosial adalah kondisi terpenuhinya kebutuhan material, spiritual, dan sosial warga negara agar dapat hidup layak dan mampu mengembangkan diri, sehingga dapat melaksanakan fungsi sosialnya."

Hal ini menjadi masalah penting dan mendesak bagi pemerintah khususnya pemerintah daerah dalam hal penanganan masalah anak remaja yang terlantar, karena jika tidak ditangani dengan sungguh-sungguh maka akan berakibat pada timbulnya masalah sosial yang serius di kalangan remaja seperti kriminalitas, penyalahgunaan obat-obat terlarang, serta hal negatif lainnya yang dapat merusak generasi penerus bangsa. Seperti halnya pada Panti Sosial Bina Remaja (PSBR) Majar Tabela Kota Palangka Raya Provinsi Kalimantan Tengah, memiliki tugas untuk memberikan pelayanan dan rehabilitasi sosial dengan tujuan agar anak remaja penyandang masalah sosial mampu melaksanakan fungsi sosial secara wajar setelah mendapatkan pelayanan sosial berupa bimbingan fisik, mental, sosial, dan latihan keterampilan. Keempat komponen bimbingan tersebut merupakan satu kesatuan yang utuh guna mempersiapkan remaja agar memiliki fisik yang sehat, mental yang kuat untuk mampu hidup bersama orang lain dengan komunikasi dan toleransi serta memiliki sikap setia kawan yang didukung dengan keterampilan yang memadai agar menjadi manusia yang produktif.
Hal penting yang menyangkut pelayanan pendidikan dan latihan keterampilan tersebut adalah tersedianya instruktur atau pelatih yang berkualitas, sehingga diharapkan hasil pendidikan atau pelatihan yang diperoleh dapat meningkatkan keterampilan remaja binaan untuk dapat mampu mandiri dalam berusaha sesuai dengan bidang keahlian yang diperolehnya.

Namun pada kenyataannya kualitas dan keahlian yang profesional dari seorang instruktur khususnya yang bertugas pada Panti Sosial Bina Remaja (PSBR) Majar Tabela di Kota Palangka Raya masih belum merata dan masih belum maksimal, sehingga hasil atau output yang diharapkan dari pendidikan dan pelatihan keterampilan dimaksud masih kurang berkualitas atau masih belum memenuhi harapan. Hal ini mungkin disebabkan antara lain oleh pola rekruitmen instruktur yang tidak memenuhi standar kualitas, kurangnya tenaga terdidik di bidang keahlian yang diperlukan, sarana prasarana yang masih belum lengkap, materi pelatihan yang kurang tepat dan sebagainya. Maka oleh sebab itu perlu dikaji sejauhmana kinerja seorang instruktur yang bertugas untuk melatih remaja binaan pada Panti Sosial Bina Remaja (PSBR) Majar Tabela di Kota Palangka Raya.

\section{METODOLOGI}

Dalam penelitian ini menggunakan pendekatan kualitatif. Dengan metode kualitatif peneliti dapat mengetahui cara pandang penelitian lebih mendalam dan lebih sesuai untuk mengetahui dan menggambarkan serta menganalisis berdasarkan datadata yang diperoleh melalui kegiatan observasi, wawancara dan dokumentasi mengenai kinerja instruktur dalam pendidikan dan pelatihan keterampilan di Panti Sosial Bina Remaja (PSBR) Majar Tabela di Kota Palangka Raya yang dilihat dari 6 (enam) indicator yaitu quality (kualitas), quantity (kuantitas), timeliness (ketepatan waktu), cost effectiveness 
(efektivitas), need for supervision (kemandirian), dan interpersonal impact (komitmen kerja).

Sumber data primer dalam penelitian ini adalah Kepala Panti Sosial Bina Remaja (PSBR) Majar Tabela di Kota Palangka Raya, Pelatih/instruktur, dan remaja binaan pada Panti Sosial Bina Remaja Majar Tabela di Kota Palangka Raya.

\section{HASIL DAN PEMBAHASAN}

Panti Sosial Bina Remaja adalah Unit Pelaksana Teknis pada Dinas Sosial yang merupakan suatu badan atau tempat yang dikhususkan untuk menampung para remaja yang putus sekolah dimana mereka akan di berikan pelatihan dan keterampilan. Kinerja instruktur pendidikan dan pelatihan (diklat) di Panti Sosial Bina Remaja (PSBR) Majar Tabela Kota Palangka Raya berdasarkan kriteria pengukuran yang dikemukakan oleh Bernardin dan Russel sebagai berikut :

I. Quality (Kualitas)

Kualitas pekerjaan ini berhubungan dengan mutu yang dihasilkan oleh para instruktur dalam memberikan bimbingan dan keterampilan di Panti Sosial Bina Remaja (PSBR) Majar Tabela, dimana kualitas pekerjaan ini mencerminkan tingkat kepuasan dalam penyelesaian pekerjaan dan kesesuaian pekerjaan yang diharapkan oleh Kepala Panti Sosial Bina Remaja (PSBR) Majar Tabela. Selain itu kualitas juga bisa diukur dengan melihat kesesuaian antara pekerjaan yang dilakukan instruktur dengan yang menjadi tanggungjawabnya atau yang sudah terjadwal sehingga pekerjaan yang dilakukan berdasarkan input yang ada akan mencapai target/sasaran kerja yang ditetapkan.

Pemberian nilai kualitas/mutu pekerjaan ini diberikan melalui pengamatan oleh atasan/pejabat penilai masing-masing instruktur. Penilaian ini dilakukan dengan membandingkan tugas dan tanggungjawab instruktur dengan hasil yang dikerjakan instruktur, dengan demikian maka akan terlihat apakah ada kesenjangan/perbedaan antara hasil dengan rencana kerja yang dibebankan kepada instruktur pendidikan dan pelatihan (diklat) di Panti Sosial Bina Remaja (PSBR) Majar Tabela.

\section{Gambar I.}

Pelatihan Keterampilan Otomotif

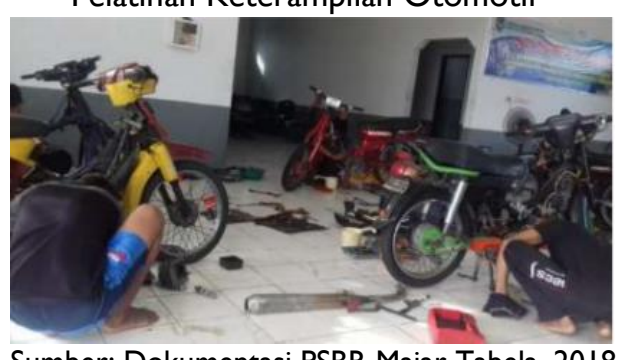

Sumber: Dokumentasi PSBR Majar Tabela, 2018

Gambar 2.

Pelatihan Keterampilan Menjahit

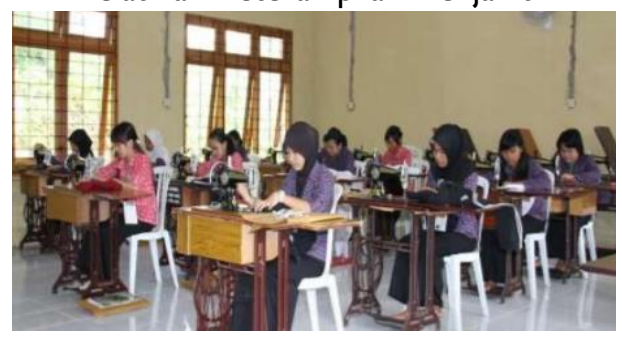

Sumber: Dokumentasi PSBR Majar Tabela, 2018

Berdasarkan hasil penelitian, terlihat bahwa instruktur baik instruktur bidang otomotif maupun instruktur bidang menjahit sudah melaksanakan tugasnya sesuai dengan jadwal yang dibuat oleh Kepala Panti Sosial Bina Remaja (PSBR) Majar Tabela sehingga dapat katakan secara keseluruhan kualitas instruktur adalah baik. Bentuk dari pelaksanaan tanggungjawab instruktur adalah melaksanakan bimbingan dan keterampilan otomotif selama 85 jam latihan (jamlat), menjahit pakaian laki-laki selama 85 jamlat, memberikan psikologi remaja selama 10 jamlat, pengembangan potensi klien selamat 22 jamlat, melatih home industri selama 35 jamlat serta melakukan pendampingan untuk kegiatan peraturan barisberbaris, senam, kerja bakti dan pendidikan agama, baik pendidikan agama Islam maupun Pendidikan agama Kristen. Pengukuran kualitas pekerjaan ini 
dilakukan oleh Kepala Panti Sosial Bina Remaja (PSBR) Majar Tabela melalui pertimbangan sumbersumber yang diperoleh. Misalnya dengan melibatkan semua pegawai yang terkait dalam pekerjaan tersebut yang dapat menjadi sumber informasi untuk menilai proses pelaksanaan pekerjaan tersebut. Dengan melibatkan semua individu yang terkait, penilaian ini dapat dikatakan bersifat partispatif dan memungkinkan penilaian terhadap kualitas pekerjaan dapat lebih akurat dan akuntabel.

Selain itu, kualitas instruktur pendidikan dan pelatihan (diklat) di Panti Sosial Bina Remaja (PSBR) Majar Tabela juga dapat dilihat dari kompetensi yang dimiliki oleh instruktur yaitu rata-rata tingkat pendidikan adalah Diploma III (D3), memiliki sertifikat keterampilan dan ada instruktur yang magang di Jepang selama 2 (dua) tahun.

Bedasarkan uraian di atas maka dapat dikatakan bahwa kinerja instruktur pendidikan dan pelatihan (diklat) di Panti Sosial Bina Remaja (PSBR) Majar Tabela dilihat dari aspek quality sudah baik, sebagaimana hasil pekerjaan sudah sesuai dengan jadwal bimbingan dan keterampilan yang telah ditetapkan oleh Kepala Panti Sosial Bina Remaja (PSBR) Majar Tabela.

2. Quantity (Kuantitas)

Aspek kuantitas adalah aspek yang menggambarkan tingkat kesesuaian antara jumlah yang dihasilkan, diberikan, atau diselesaikan dalam suatu tugas pokok seorang instruktur pendidikan dan pelatihan (diklat) di Panti Sosial Bina Remaja (PSBR) Majar Tabela, dengan target yang telah dibuat dalam tugas pokok tersebut dalam bentuk jadwal bimbingan dan keterampilan. Kuantitas pekerjaan dapat diperoleh dari hasil pengukuran kerja atau penetapan tujuan partisipatif dari penyelenggaraan bimbingan dan keterampilan di
Panti Sosial Bina Remaja (PSBR) Majar Tabela yang dilaksanakan selama 5 (lima) bulan.

Dalam penilaian kuantitas pekerjaan ini, masing-masing instruktur dinilai seberapa banyak pekerjaan yang harus dilakukan dalam tugas jabatannya selama 5 (lima) bulan. Tugas dan pekerjaan tersebut untuk melaksanakan bimbingan dan keterampilan kepada klien yang dilakukan dalam kurun waktu satu bulan untuk teori, tiga bulan untuk praktek dan satu bulan untuk magang. Teori dilaksanakan di ruang kelas, praktek dilakukan di tempat praktikum, untuk magang dilaksanakan di mitra kerja yaitu di bengkel Honda, bengkel Yamaha, dan bengkel Jogja untuk otomotif, sedangkan untuk magang keterampilan menjahit di Penjahit Ida Pasar Kahayan. Berdasarkan data yang diperoleh, dengan melihat target output pekerjaan dan hasil yang dapat direalisasikan oleh instruktur maka dapat dilihat bahwa setiap instruktur pendidikan dan pelatihan (diklat) di Panti Sosial Bina Remaja (PSBR) Majar Tabela telah menyelesaikan tugas dan tanggungjawabnya sesuai dengan target pekerjaan yang telah ditetapkan berdasarkan jadwal bimbingan dan keterampilan. Ini menunjukkan bahwa untuk kuantitas dari beban pekerjaan yang diberikan terhadap masing-masing instruktur tidak menjadi masalah dan mampu diselesaikan oleh masing-masing instruktur, sehingga tidak perlu mengurangi beban pekerjaan dan bahkan mungkin dapat diberikan tugas yang lebih. Namun lebih jauh dalam mengukur aspek kuantitas ini, tentunya tidak hanya dilihat dari seberapa banyak ataupun seberapa besar beban kerja yang diselesaikan oleh instruktur setiap tahunnya, tentunya harus dikaitkan dengan aspek kualitas, waktu dan biaya sehingga pada akhirnya dapat disimpulkan apakah pekerjaan yang dilakukan oleh masing-masing instruktur dapat dikatakan telah memenuhi 
harapan dan menunjang pencapaian tujuan Panti Sosial Bina Remaja (PSBR) Majar Tabela.

Namun dalam penelitian ini juga ditemukan bahwa secara kuantitas personal dari instruktur hanya berjumlah 4 (empat) orang saja yaitu dua instruktur bidang otomotif dan 2 (dua) orang instruktur bidang keterampilan menjahit. Dengan beban mengajar, praktek dan magang seyogyanya jumlah instruktur sebanyak 8 (delapan) orang sehingga bisa bekerja bergantian sesuai dengan bidangnya masing-masing. Salah satu kendala yang ditemukan akibat kurangnya jumlah instruktur adalah apabila ada instruktur yang berhalangan hadir maka jam mengajarnya tidak ada yang menggantikan sehingga jam mengajar menjadi kosong, hal ini berdampak pada klien yang tidak mendapatkan bimbingan dari instruktur yang berhalangan tadi. Namun apabila kuantitas instruktur memadai, masalah tersebut bisa diatasi dengan digantikan oleh instruktur yang lain.

3. Timeliness (Ketepatan Waktu)

Ketepatan waktu ini berhubungan dengan waktu penyelesaian tugas (pekerjaan) sesuai dengan waktu yang diberikan. Setiap pekerjaan yang dilakukan oleh para instruktur pendidikan dan pelatihan (diklat) di Panti Sosial Bina Remaja (PSBR) Majar Tabela memiliki standar waktu yang telah ditentukan. Visi dan misi Panti Sosial Bina Remaja (PSBR) Majar Tabela akan tercapai apabila pekerjaan yang dilakukan oleh para instruktur dapat dilaksanakan sesuai dengan waktu yang telah ditentukan, dalam hal ini diantaranya; ketepatan waktu dalam menyelesaikan bimbingan dan keterampilan sesuai dengan jadwal yang telah ditetapkan. Dari hasil penelitian yang dilakukan, instruktur yang menjadi subyek penelitian mampu melaksanakan tugas tepat pada waktunya dalam kurun waktu 5 (lima) bulan yang digunakan untuk kegiatan bimbingan teori selama I (satu) bulan, praktek keterampilan selama 3 (tiga) bulan dan magang kerja selama I (satu) bulan. Dalam bimbingan dan keterampilan baik otomotif maupun menjahit telah terjadwal lamanya kegiatan, misalnya pendidikan agama Islam atau Kristen selama 12 Jamlat, bimbingan agama Islam atau Kristen selama 8 Jamlat, bimbingan genarasi muda selama 10 Jamlat, dan pengembangan potensi selama 22 Jamlat.

Namun didalam penelitian ini pengkuran waktu penyelesaian belum mampu mengukur secara akurat, karena meskipun rata-rata instruktur dapat menyelesaikan pekerjaan secara tepat waktu, tetapi kadang masih terkendala dalam keterlambatan menyelesaikan kegiatan yang intensif seperti kegiatan yang dilakukan dalam bimbingan teori pada bulan pertama, praktek pada bulan kedua sampai keempat, dan kegiatan magang pada bulan kelima. Hal ini disebabkan karena jumlah instruktur yang belum memadai hanya berjumlah 4 (empat) orang saja instruktur Panti Sosial Bina Remaja (PSBR) Majar Tabela.

\section{Gambar 3.}

Jadwal Bimbingan dan Keterampilan

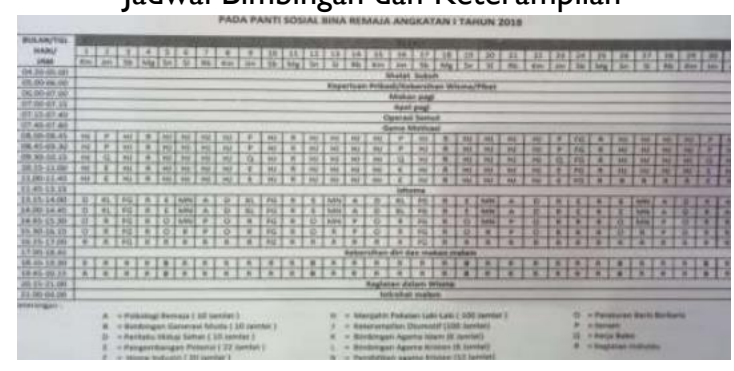

Sumber: Dokumentasi PSBR Majar Tabela, 2018

\section{Cost Effectiveness (Efektivitas)}

Efektivitas biaya di sini mengenai tingkatan penggunaan sumber dana organisasi yang menyangkut penggunaan keuangan dimaksimalkan untuk mendapatkan hasil yang tertinggi atau pengurangan kerugian dari tiap unit. Didalam melaksanakan tugasnya para instruktur diharapkan untuk dapat memberdayakan/menggunakan segala 
sumber daya keuangan yang ada di dalam organisasi yang bersangkutan guna membantu penyelesaian tugas pekerjaan baik dari segi waktu maupun hasil kerja.

Hasil penelitian menunjukkan bahwa biaya penyelenggaraan bimbingan dan keterampilan di Panti Sosial Bina Remaja (PSBR) Majar Tabela Kota Palangka Raya bersumber dari Anggaran Pendapatan dan Belanja Daerah Provinsi Kalimantan Tengah melalui Dinas Sosial Provinsi Kalimantan Tengah. Anggaran tersebut digunakan untuk gaji pegawai, honor tenaga kontrak, honor instruktur, biaya konsumsi klien dan biaya operasional penunjang penyelenggaraan bimbingan dan keterampilan serta biaya taktis kegiatan.

Dalam hasil penelitian ini terlihat bahwa ratarata instruktur mendapat honor sebesar Rp. 20.000 per jam. Apabila dalam satu hari mendapatkan jadwal latihan (jamlat) selama 5 (lima) jam, maka pendapatan atau honor instruktur per hari sebesar Rp. 100.000,--. Jumlah yang relatih masih kecil, namun dari hasil penelitian terlihat bahwa instruktur yang membimbing di Panti Sosial Bina Remaja (PSBR) Majar Tabela tidak berorientasi pada besarnya pendapatan, tetapi cenderung melihat dari aspek sosial dan pengabdian untuk generasi muda sehingga mereka bisa mandiri, membuka lapangan kerja sendiri tanpa harus menunggu adanya lowongan pekerjaan.

Efektivitas biaya penyelenggaraan bimbingan dan pelatihan di Panti Sosial Bina Remaja (PSBR) Majar Tabela merupakan salah satu upaya agar penyelenggaran pendidikan dan pelatihan (diklat) dapat berjalan dengan lancar dan berkelanjutan. Dengan sistim akuntabilitas dan transparansi penggunaan anggaran yang jelas maka penggunaan anggaran dapat dipertanggungjawabkan kepada publik. Namun sebaliknya apabila penggunaan anggaran tidak efektif dan efisien maka tidak menutup kemungkinan terjadinya penyalagunaan anggaran.

Sebagaimana pendapat Pasolong (2008) bahwa salah satu indicator yang digunakan untuk mengukur kinerja adalah aspek efesiensi, yaitu membandingkan keberhasilan kerja dengan biaya yang dikeluarkan. Apakah anggaran yang dikeluarkan sebanding dengan hasil yang didapatkan. Sedangkan dilihat dari hasil penelitian bahwa honor untuk instruktur bisa dibilang masih rendah hanya Rp. 20.000 per jam dengan beban kerja yang begitu besar mulai dari bimbingan teori, praktek dan magang kerja. Berkaitan dengan penggunaan anggaran dalam kegiatan bimbingan dan keterampilan di Panti Sosial Bina Remaja (PSBR) Majar Tabela akan dipertanggungjawabkan setiap akhir kegiatan oleh Kepala Panti Sosial Bina Remaja (PSBR) Majar Tabela kepada Kepala Dinas Sosial Provinsi Kalimantan Tengah. Dari laporan keuangan itu, dapat dievaluasi penggunaan anggaran apakah sudah efektif apa belum. Apabila ditemukan kekurang- efektivan penggunaan anggaran maka akan dilakukan pembenahan terhadap pos-pos anggaran penyebab kekurangefektivan sehingga pada kegiatan bimbingan dan keterampilan di Panti Sosial Bina Remaja (PSBR) Majar Tabela pada masa mendatang dapat lebih efektif.

5. Need for Supervision (Kemandirian)

Kemandirian dalam melaksanakan tugas sebagai instruktur merupakan bentuk kesiapan instruktur untuk menjalankan tugas dan tanggungjawabnya. Kemandirian dapat berupa kesiapan secara psikologis untuk menghadapi klien yang mau dibimbing, kesiapan untuk menyampaikan materi pembelajaran, kesiapan untuk menghadapi pertanyaan, kesiapan untuk berbeda pendapat, dan kesiapan untuk 
menghadapi klien yang ribut atau ramai di kelas. Selain itu, kemandirian seorang instruktur juga terlihat dari kesiapan dengan bahan ajar/diklat/modul pembelajaran, kesiapan dengan sarana penunjang (laptop, LCD, ruang kelas, dan ruang praktikum).

Berdasarkan hasil wawancara dan observasi terlihat bahwa instruktur pendidikan dan pelatihan (diklat) di Panti Sosial Bina Remaja (PSBR) Majar Tabela sebagian sudah mandiri baik secara psikis, maupun secara teknis. Namun masih ada instruktur muda yang masih mengalami kendala teknis berkaitan dengan pembuatan laporan akhir dan evaluasi kegiatan. Hal ini disebabkan karena instruktur muda khususnya yang honorer masih belum terbiasa untuk membuat laporan akhir dan evaluasi kegiatan bimbingan dan keterampilan. Namun demikian, berkat adanya komunikasi dan koordinasi yang baik antara instruktur dengan Kepala Panti Sosial Bina Remaja (PSBR) Majar Tabela dan dengan instruktur yang lebih senior, kendala tersebut bisa diatasi dengan baik. Hubungan kerja baik dengan atasan maupun rekan kerja merupakan suatu yang penting karena disana terdapat hubungan timbal balik yang saling membutuhkan, saling mendukung, saling memotivasi dan saling kerja sama guna mencapai tujuan penyelenggaraan bimbingan dan keterampilan di Panti Sosial Bina Remaja (PSBR) Majar Tabela.

6. Interpersonal Impact (Komitmen Kerja)

Komitmen kerja instruktur pendidikan dan pelatihan (diklat) di Panti Sosial Bina Remaja (PSBR) Majar Tabela sudah baik. Hal ini dibuktikan dibuktikan dengan kinerja instruktur melaksanakan tugas dan tanggungjawab sesuai dengan jadwal bimbingan dan keterampilan. Selain itu, komitmen instruktur terlihat dari kesiapannya secara mandiri untuk melaksanakan tugas dan tanggungjawabnya dengan baik yang terlihat dari kesiapan dalam membuat modul pembelajaran, power point bahan ajar dan kesiapan dalam membimbing praktek dan magang kerja atau Praktek Belajar Kerja (PBK).

Setiap instruktur yang bekerja harus mempunyai komitmen untuk melaksanakan tugasnya dengan baik. Tanpa adanya komitmen dari instruktur maka penyelenggaraan bimbingan dan pelatihan di Panti Sosial Bina Remaja (PSBR) Majar Tabela bisa saja terlaksana, namun belum tentu optimal. Untuk itu komitmen kerja sangat penting dalam memotivasi kinerja instruktur. Namun terkadang pihak pengelola kurang memperhatikan komitmen instruktur, sehingga berdampak pada penurunan kinerja instruktur ataupun berkurangnya tingkat loyalitas. Untuk itu, pengelola Panti Sosial Bina Remaja (PSBR) Majar Tabela juga harus memberikan nilai keseimbangan terhadap komitmen instruktur dengan memberikan penghargaan yang sepantasnya bagi kinerja instruktur pendidikan dan pelatihan (diklat) di Panti Sosial Bina Remaja (PSBR) Majar Tabela. Meskipun dalam hati nurani, para instruktur tidak mungkin melakukan protes atau demo karena rendahnya honor yang diterima sebesar $\mathrm{Rp}$. 20.000 per jam.

Berdasarkan hasil penelitian juga terlihat adanya komitmen kerjasama antara instruktur dengan pengelola Panti Sosial Bina Remaja (PSBR) Majar Tabela, maupun antar instruktur. Kerjasama atau teamwork merupakan modal yang terpenting didalam menyelesaikan pekerjaan. Didalam sebuah organisasi tentunya setiap program kerja tidak terlepas dari kebutuhan kerjasama tim (teamwork) karena setiap program kerja pasti dilaksanakan secara tim dan bukan individu saja, walaupun dalam pembagian tugas dan pekerjaan masing-masing instruktur bertanggungjawab pada bidangnya masing. 


\section{KESIMPULAN}

Berdasarkan analisis dari hasil penelitian dilapangan terkait kinerja instruktur pendidikan dan pelatihan (diklat) keterampilan pada Panti Sosial Bina Remaja (PSBR) Majar Tabela Kota Palangka Raya dapat disimpulkan dari aspek quality, quantity, timeliness, cost effectiveness, need for supervision, dan interpersonal impact masih kurang optimal. Hal ini bisa dilihat dari aspek quantity yaitu masih kurangnya jumlah instruktur yang ada minimal 6 (enam) sampai 8 (delapan) orang, sedangkan yang ada sekarang hanya 4 (empat) instruktur saja. Kemudian dari aspek need for supervision, masih ada instruktur yang kurang mandiri, khususnya berkaitan dengan pembuatan laporan dan evaluasi pembelajaran. Hal ini disebabkan instruktur tersebut merupakan instruktur yang baru direkrut sehingga masih kurang berpengalaman dalam membuat laporan dan evaluasi kegiatan. Sehingga menyebabkan aspek timeliness juga terdampak dengan keterlambatan dalam membuat laporan kegiatan.

\section{REFERENSI}

Busro Muhammad. 2018. Teori-Teori Manajemen Sumber Daya Manusia. Prenada media Group. Jakarta.

Byars, I. Rue, Leslie W. 2006. Human Resource Management. 8th Edition. McGraw Hill Inc. New York.

Deddy, Mulyana. 2004. Metodologi Penelitian Kualitatif. PT Remaja Rosdakarya. Bandung.

Gunarsa, Singgih D. 2004. Psikologi Perkembangan Anak dan Remaja. Gunung Mulia. Jakarta.

Hamalik, O. 200I. Manajemen Pelatihan dan Ketenagakerjaan. Bumi Aksara. Jakarta.

Hurlock, E.B. 2005. Perkembangan Anak (Jilid I). Erlangga. Jakarta.

Keban, T. Yeremias. 2004. Enam Dimensi Strategis Administrasi Publik, Konsep, Teori dan Isu. Gava Media. Yogyakarta.
Mahsun, Mohamad. 2013. Pengukuran Kinerja Sektor Publik. BPFE. Yogyakarta.

Mangkunegara, A.P. 20I4. Evaluasi Kinerja SDM. Refika Aditama. Bandung.

Mathis, R.L. dan Jackson, J.H. 2006. Human Resource Management: Manajemen Sumber Daya Manusia. Terjemahan Dian Angelia. Salemba Empat. Jakarta.

Mukarom Zaenal dan Laksana Muhibudin Wijaya. 2016. Membagun Kinerja Pelayanan Publik Menuju Clean Government and Good Governance. CV Pustaka Setia. Bandung.

Sudarmanto. 2009. Kinerja dan Pengembangan Kompetensi SDM. Pustaka Pelajar. Yogyakarta.

Wibowo. 2007. Manajemen Kinerja. PT.Raja Grafindo Persada. Jakarta.

Yusuf, Ria Mardiana dan Syarif, Darman. 2017. Komitmen Organisasi. CV Nas Media Pustaka. Makassar. 